\title{
Research and Application on Professional Information Management and Evaluation Platform for Higher Vocational Education
}

\author{
Xiaohong Liu ${ }^{\mathrm{a}}$, Guangfu Zhu ${ }^{\mathrm{b}}$, Suran Yang ${ }^{\mathrm{c}}$ \\ Information center, Chongqing City Management College, Chongqing, China \\ a19568838@qq.com, b149189515@qq.com, '99770816 @qq.com
}

\begin{abstract}
Keywords: higher vocational education; professional information management, professional evaluation; professional development; professional reform
\end{abstract}

\begin{abstract}
With the rapid development of computer technology and network information technology, people tend to use the Internet and information technology to standardize the process, simplify the procedures and improve the efficiency. The research and application on the professional information management and evaluation platform for higher vocational education will be helpful to promote the construction and optimization of the specialty group of higher vocational education and improve the teaching level and the quality of personnel training. The purpose of this study is to construct higher vocational education in the specialty of information management and evaluation platform, construct the evaluation system of professional line, promote the establishment of a scientific evaluation system, simplify the evaluation process, save the cost of the assessment, reduce the subjective influence of the assessment process, realize the professional assessment of the open and fair, promote the healthy development of the professional construction of higher vocational education and provide data support for professional diagnosis and continuous improvement. The main method is the use of information management platform for data analysis, improvement and optimization of the development of good professional and early warning or elimination of small or outdated social needs of professional. Through this study, we can enhance the professional development of higher vocational education the overall information management level and application level, promote higher vocational specialty construction and reform of education by means of informationization and cultivate practical talents the society needs.
\end{abstract}

\section{Introduction}

In order to guide higher vocational colleges to strengthen the professional construction, promote the development of professional connotation and enhance the level of professional information management, it is imperative to build a set of information systems for professional management and evaluation. The Professional Information Management and Evaluation Platform for Higher Vocational Education includes the use of the Internet, the assessment of professional assessment agencies, project evaluation, evaluation experts, evaluation index, basic data set and maintenance and management and analysis of the relevant professional jurisdiction within the scope of the application of information technology. The unit which is evaluated can submit the relevant information and the supporting materials such as online reporting and management and analysis on the professional assessment of experts. It can change the traditional evaluation model, which means the evaluated school no longer needs to enter the scene. Via the Internet and online data acquisition and analysis evaluation, we can deal with evaluating the major and make the evaluation conclusion. This greatly improves the efficiency of the parties to assess and reduces the cost of assessment [1]

\section{Problems in the Evaluation of Higher Vocational Education}

Professional Evaluation Index System is not Closely Linked with the Industry. Professional evaluation index system design needs to guide the professional development of higher vocational education, meet the needs of economic development and train specifications. The professional 
construction industry economic development areas are fully reflected in the talent, effectively serving the local industrial transformation and upgrading. In higher vocational education, professional and industrial docking is to do a professional chain and industrial chain docking, professional structure and industrial structure docking, specialty setting and employment market docking based on full market research on.

Means of Evaluation is not Perfect, cannot Adapt to Professional Diagnosis and Continuous Improvement. The professional assessment of the workload is huge, while the traditional way of evaluation means single, rough, generally using sampling methods to assess. So the evaluation is not comprehensive, which cannot fully expose the existing problems in major construction and no improvement for timely diagnosis of hidden problems. If we want to carry on the diagnosis and the improvement, we must take a large amount of data analysis and statistics as the main means to find the problems in the construction and development of the specialty. Therefore, it is imperative to improve the evaluation means through information technology.

The Accuracy, Real-time and Convenience of Data Acquisition are Weak. The traditional professional assessment process mainly adopts manual mode, so the assessment materials to paper documents are in school data reporting, data collection often comes from different departments. Collecting the data source is not unified and data acquisition is difficult. There are different document data inconsistencies. In the process of data collection, there is no information support, so the accuracy of the data and real-time is difficult to be guaranteed.

Lack of Analysis of the Evaluation Data and Professional Construction. There is no support for the information system of traditional professional evaluation, which cannot be forced to reform and construction by feedback diagnosis report and improvement suggestions. Professional evaluation requires the establishment of process and quality evaluation and diagnosis mechanism in Higher Vocational Colleges in the process of professional construction, and targeted to improve the results of the assessment. The traditional evaluation methods can neither effectively evaluate the data analysis nor find the singular points in time, so it is difficult to achieve the diagnosis of professional construction.

Evaluation of the Performance of the Work itself is not Effective. To organize and meet the professional assessment of the work is very heavy and the entire assessment process involves a wide range of participants. The workload is large with complex statistics and low efficiency. If the assessment process is lack of information means, evaluation personnel is difficult to evaluate material to control and grasp of the assessment indicators. The assessment data statistics and analysis cannot be dealt with effectively and timely and historical data are difficult to be reused. Therefore, in the process of evaluation, there are some phenomena, such as inaccurate evaluation, low efficiency and large error.

\section{Professional Information Management and Evaluation Platform Research}

Higher Vocational Education Information Management and Evaluation Platform Needs Analysis. Professional information management and evaluation platform is the use of Internet, information technology and other means of professional assessment of Higher Vocational Colleges online reporting, online review, and online management information management system. Through the application of this platform, we can reflect the "Internet plus evaluation" advantage, collect data from the source and ensure the authenticity of the data and real-time accuracy; data analysis and display in the full range, which can improve the evaluation efficiency, low cost and evaluation in the process of high transparency, fairness and justice goals [2, 3, 4].

The platform should facilitate the school self-management professional, provide the basis for evaluation of data report and scientific and accurate for the construction of two faculties of professional self, provide data for a professional analysis, find out the professional construction of the short board, and promote continuous improvement of professional construction. The platform should 
also provide a comprehensive data query, comparison and analysis for the education department to help the decision support for the overall planning and management of Higher Vocational colleges.

Higher vocational education information management and evaluation platform system framework diagram shown in figure 1.

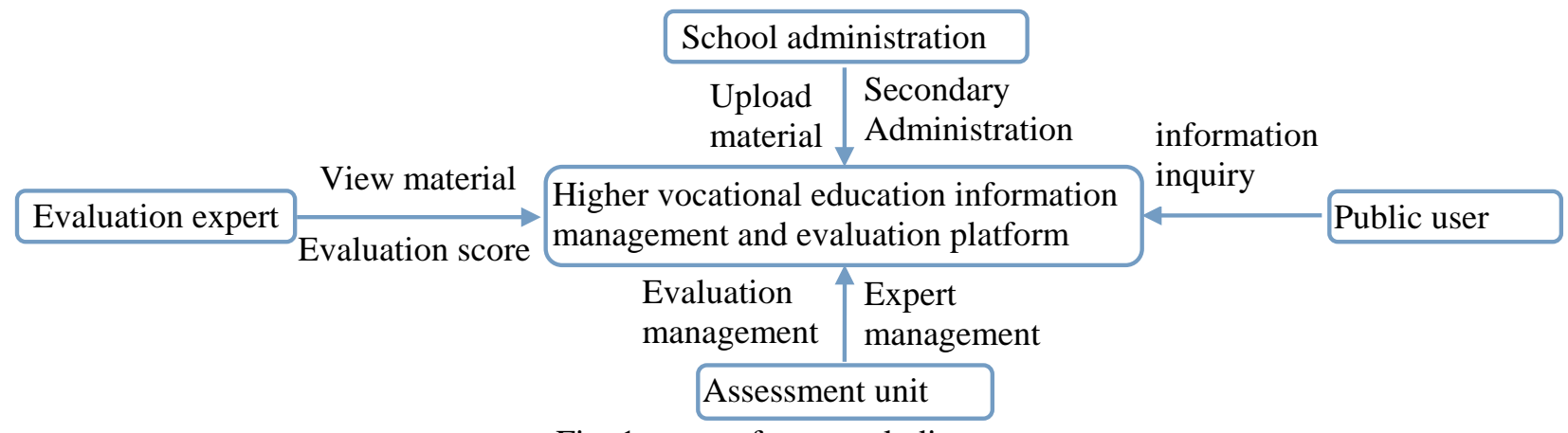

Fig. 1 system framework diagram

Main Functions of Information Management and Evaluation Platform for Higher Vocational Education. Higher vocational education information management and evaluation platform owns four subsystems, i.e. expert school data acquisition subsystem, evaluation subsystem, project management subsystem and the public inquiry subsystem, which respectively meet the higher vocational colleges, evaluation experts and the administrative departments of education in the specialty of information management and professional analysis and evaluation requirements, which is open to the public query data. The main functions of the system are shown in figure 2.

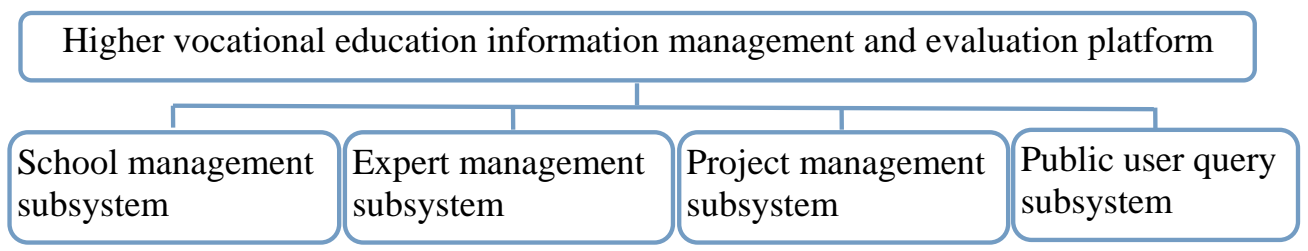

Fig. 2 main functions of the system

School Management Subsystem. The function of the school contains information maintenance, professional information management and professional support materials upload functions. The decomposition of the school subsystem is shown in figure 3.

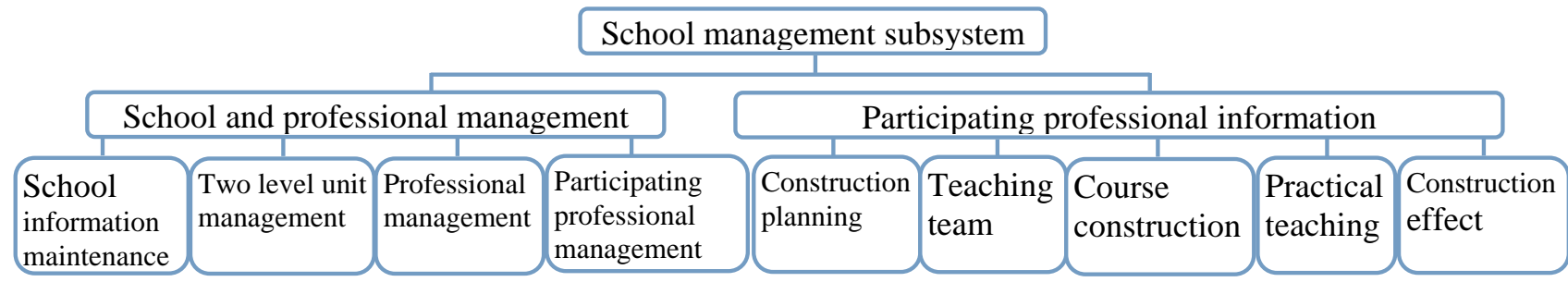

Fig. 3 function decomposition diagram of school subsystem

Expert Management Subsystem. To achieve the evaluation expert online information browsing, online scoring and other functions. Expert evaluation subsystem function decomposition diagram is shown in figure 4 .

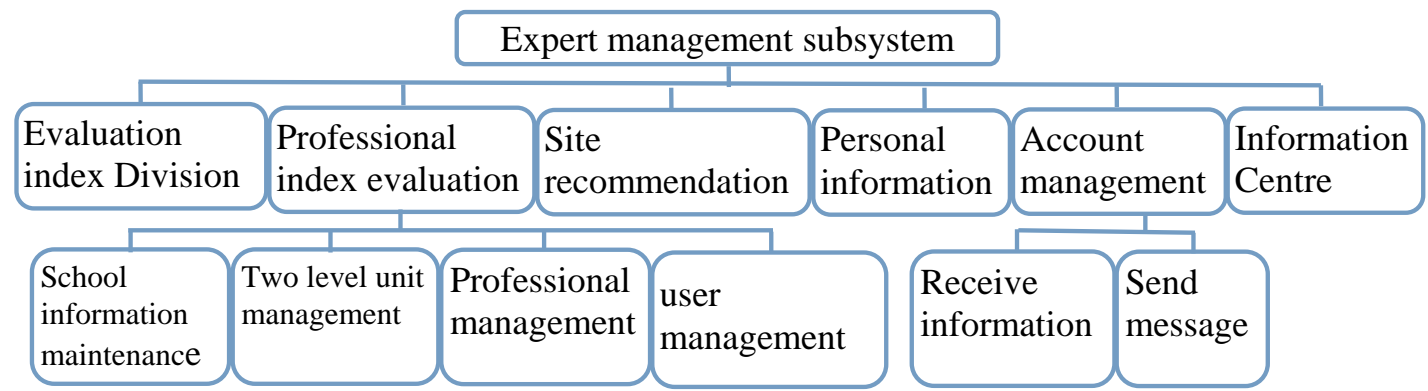

Fig. 4 function decomposition of expert evaluation subsystem 
Project Management Subsystem. The main achievement of the basic data setting includes assessment project settings, professional inquiries and expert library management functions. The function decomposition diagram of the project management subsystem is shown in figure 5.

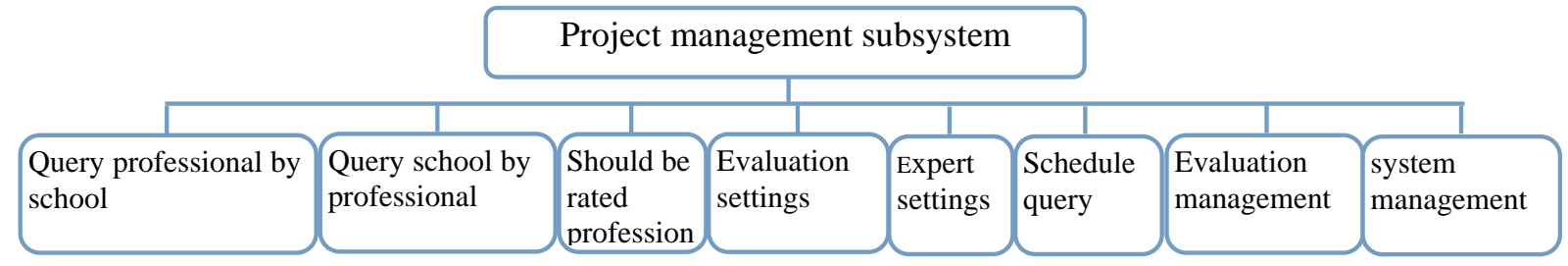

Fig. 5 function decomposition diagram of project management subsystem

Public User Query Subsystem. To achieve the demand for public information query for public users. Public information query subsystem decomposition diagram as shown in figure 6.

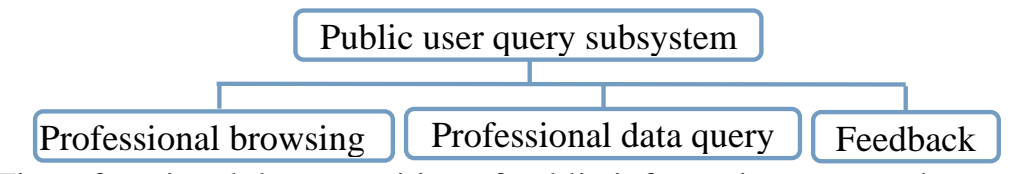

Fig. 6 functional decomposition of public information query subsystem

\section{Analysis and Application of Information Management and Evaluation Platform for Higher Vocational Education}

Under the careful organization and overall planning of a regional evaluation organization, this paper completed the two years of 2015 and 2016 two years in the area of Higher Vocational network evaluation work in. Through two years of practice, a large number of professional construction data has formed. For evaluation, professional departments and professional construction and management in Higher Vocational Colleges self-diagnosis, self-improvement can provide data support for the region; assessment of the group of experts can provide a comprehensive understanding of the overall level of professional. According to the evaluation indicators of the professional, the result can provide data support for professional layout; for the professional management of the region, it can provide data support for professional adjustment. Comparative analysis of the evaluation data.

Analysis of Participants in the Professional Assessment (2014, 2015, and 2016). The platform realizes the interaction with the professional teachers, collects the data from the source, strengthens the policy guidance to the vocational education workers and promotes the docking of the curriculum content and the professional standard. Analysis of participants in the professional assessment as shown in table 1.

Table 1 analysis of participants in the professional assessment

\begin{tabular}{|c|c|c|c|c|}
\hline participate in & $\begin{array}{c}2014 \\
\text { (No enabled) }\end{array}$ & 2015 & 2016 & Influence \\
\hline Professional level & $\begin{array}{l}\text { Major professional } \\
\text { management teacher }\end{array}$ & $\begin{array}{l}\text { Every } \\
\text { professional } \\
\text { teacher }\end{array}$ & $\begin{array}{l}\text { Every } \\
\text { professional } \\
\text { teacher }\end{array}$ & $\begin{array}{l}\text { Benefit all aspects of } \\
\text { professional } \\
\text { construction }\end{array}$ \\
\hline School level & $\begin{array}{l}\text { Academic } \\
\text { Coordinator }\end{array}$ & $\begin{array}{l}\text { School, two } \\
\text { Department of } \\
\text { professional } \\
\text { managers }\end{array}$ & $\begin{array}{l}\text { School, two } \\
\text { Department of } \\
\text { professional } \\
\text { managers }\end{array}$ & $\begin{array}{l}\text { Benefit from all levels } \\
\text { of professional } \\
\text { construction }\end{array}$ \\
\hline Evaluation expert & Evaluation expert & $\begin{array}{l}\text { Evaluation } \\
\text { expert }\end{array}$ & Evaluation expert & \multirow{2}{*}{$\begin{array}{l}\text { Allow the participants } \\
\text { to participate in the } \\
\text { professional evaluation } \\
\text { process. }\end{array}$} \\
\hline $\begin{array}{l}\text { Evaluation } \\
\text { agency }\end{array}$ & Evaluation Manager & $\begin{array}{l}\text { Evaluation } \\
\text { Manager }\end{array}$ & $\begin{array}{l}\text { Evaluation } \\
\text { Manager }\end{array}$ & \\
\hline
\end{tabular}

Analysis of Changes in Evaluation Methods (2014, 2015, and 2016). The platform realizes the full coverage of the professional evaluation, such as the real time, reality and pertinence of the data acquisition, which provides the support for the professional diagnosis and improvement. Analysis of changes in evaluation methods as shown in table 2. 
Table 2 Analysis of changes in evaluation methods

\begin{tabular}{|c|c|c|c|c|}
\hline mode year & $\begin{array}{c}2014 \\
\text { (No enabled) } \\
\end{array}$ & 2015 & 2016 & change \\
\hline $\begin{array}{l}\text { Professional } \\
\text { participation }\end{array}$ & $\begin{array}{l}\text { Sampling from } \\
10 \% \text { to } 20 \%\end{array}$ & $\begin{array}{l}\text { All professionals } \\
\text { involved in online } \\
\text { assessment, according } \\
\text { to the online } \\
\text { assessment, sampling } \\
\text { about } 20 \% \text { of the } \\
\text { professional site } \\
\text { assessment }\end{array}$ & $\begin{array}{l}\text { All professionals } \\
\text { involved in online } \\
\text { assessment, according to } \\
\text { the online assessment, } \\
\text { sampling about } 20 \% \text { of } \\
\text { the professional site } \\
\text { assessment }\end{array}$ & $\begin{array}{l}\text { According to the } \\
\text { classification data } \\
\text { processing ability } \\
\text { of the platform, the } \\
\text { professional } \\
\text { evaluation } \\
\text { participation is } \\
\text { greatly improved }\end{array}$ \\
\hline $\begin{array}{l}\text { Expert } \\
\text { evaluation }\end{array}$ & $\begin{array}{l}\text { Listen to the } \\
\text { report of the } \\
\text { sample school } \\
\text { site, check the } \\
\text { text material, } \\
\text { according to the } \\
\text { evaluation } \\
\text { elements }\end{array}$ & $\begin{array}{l}\text { Online access to text } \\
\text { materials, the discovery } \\
\text { of singular points in } \\
\text { advance, with questions } \\
\text { to verify the school, and } \\
\text { online evaluation. }\end{array}$ & $\begin{array}{l}\text { Online access to text } \\
\text { materials, analysis of the } \\
\text { platform after the } \\
\text { pretreatment of } \\
\text { professional data, the } \\
\text { discovery of singular } \\
\text { points in advance, with } \\
\text { questions to the school to } \\
\text { verify, and online } \\
\text { evaluation. }\end{array}$ & $\begin{array}{l}\text { According to the } \\
\text { function of data } \\
\text { aggregation and } \\
\text { data preprocessing, } \\
\text { the platform can } \\
\text { greatly reduce the } \\
\text { difficulty of expert } \\
\text { work }\end{array}$ \\
\hline $\begin{array}{l}\text { data } \\
\text { organization }\end{array}$ & $\begin{array}{l}\text { School } \\
\text { self-evaluation } \\
\text { report and } \\
\text { supporting } \\
\text { materials } \\
\end{array}$ & $\begin{array}{l}\text { Organize the data report } \\
\text { and supporting } \\
\text { materials according to } \\
\text { the evaluation elements }\end{array}$ & $\begin{array}{l}\text { Organize the raw data, } \\
\text { platform analysis report } \\
\text { and supporting materials } \\
\text { according to the } \\
\text { evaluation elements }\end{array}$ & $\begin{array}{l}\text { Data more real, } \\
\text { more accurate, } \\
\text { more targeted }\end{array}$ \\
\hline $\begin{array}{l}\text { Conclusion } \\
\text { feedback }\end{array}$ & $\begin{array}{l}\text { Single } \\
\text { conclusion }\end{array}$ & $\begin{array}{l}\text { Conclusion and analysis } \\
\text { of evaluation elements }\end{array}$ & $\begin{array}{l}\text { Conclusion and analysis } \\
\text { of evaluation elements }\end{array}$ & $\begin{array}{l}\text { Conclusion the } \\
\text { feedback is more } \\
\text { targeted }\end{array}$ \\
\hline $\begin{array}{l}\text { Conclusion } \\
\text { application }\end{array}$ & $\begin{array}{l}\text { Mainly used for } \\
\text { professional } \\
\text { evaluation } \\
\text { conclusions }\end{array}$ & $\begin{array}{l}\text { Conclusions of } \\
\text { professional assessment } \\
\text { and school } \\
\text { self-evaluation }\end{array}$ & $\begin{array}{l}\text { The conclusion of } \\
\text { professional assessment, } \\
\text { self assessment of school } \\
\text { and the construction of } \\
\text { professional quality } \\
\text { internal evaluation system }\end{array}$ & $\begin{array}{l}\text { More suitable for } \\
\text { professional self } \\
\text { assessment, } \\
\text { self-management, } \\
\text { self diagnosis and } \\
\text { self improvement }\end{array}$ \\
\hline
\end{tabular}

Analysis of the Change of Evaluation Results (2014, 2015, in 2016). The platform realizes the management of the index granularity, so the feedback information of the evaluation is more targeted, and it can effectively promote the continuous improvement of the professional construction. Analysis of the change of evaluation results as shown in table 3 .

Table 3 analysis of the change of evaluation results

\begin{tabular}{|c|c|c|c|c|}
\hline $\begin{array}{r}\text { year } \\
\text { conclusion }\end{array}$ & $\begin{array}{c}2014 \\
\text { (No enabled) }\end{array}$ & 2015 & 2016 & Influence \\
\hline $\begin{array}{l}\text { Assessment } \\
\text { work }\end{array}$ & $\begin{array}{l}\text { Professional } \\
\text { assessment of } \\
\text { qualified and } \\
\text { unqualified } \\
\text { notification }\end{array}$ & $\begin{array}{l}\text { Inform the } \\
\text { professional } \\
\text { assessment of } \\
\text { qualified and } \\
\text { unqualified, } \\
\text { reasons, } \\
\text { suggestions for } \\
\text { improvement, etc. }\end{array}$ & $\begin{array}{l}\text { Inform the } \\
\text { professional } \\
\text { assessment of } \\
\text { qualified and } \\
\text { unqualified, } \\
\text { reasons, } \\
\text { suggestions for } \\
\text { improvement, etc. }\end{array}$ & $\begin{array}{l}\text { The platform enables the } \\
\text { evaluation work to be more } \\
\text { efficient, more effective, to } \\
\text { promote the school and } \\
\text { professional self-assessment, } \\
\text { and promote the adjustment of } \\
\text { the professional layout in the } \\
\text { region }\end{array}$ \\
\hline $\begin{array}{l}\text { Specialty } \\
\text { construction }\end{array}$ & $\begin{array}{l}\text { Evaluation } \\
\text { results }\end{array}$ & $\begin{array}{l}\text { Give advice based } \\
\text { on assessment } \\
\text { elements }\end{array}$ & $\begin{array}{l}\text { Feedback by } \\
\text { detailed } \\
\text { evaluation } \\
\text { indicators }\end{array}$ & $\begin{array}{l}\text { The index granularity is finer, } \\
\text { the feedback information is } \\
\text { more specific, so as to promote } \\
\text { the continuous improvement of } \\
\text { professional construction }\end{array}$ \\
\hline $\begin{array}{l}\text { Expert } \\
\text { evaluation }\end{array}$ & $\begin{array}{l}\text { Field } \\
\text { investigation, } \\
\text { on-site feedback }\end{array}$ & $\begin{array}{l}\text { Online review } \\
\text { combined with } \\
\text { spot checks }\end{array}$ & $\begin{array}{l}\text { Online review } \\
\text { combined with } \\
\text { spot checks }\end{array}$ & $\begin{array}{l}\text { The evaluation results are more } \\
\text { scientific }\end{array}$ \\
\hline
\end{tabular}


Application Change Analysis from the Assessment Process Data (2014, 2015, and 2016). The platform has realized the data standardization, the informationization, the multi-dimensional data display and the analysis, providing the policy-making support for the specialized construction and the management. Application change analysis from the assessment process data as shown in table 4.

Table 4 application change analysis from the assessment process data

\begin{tabular}{|c|c|c|c|c|}
\hline $\begin{array}{c}\text { year } \\
\text { conclusion }\end{array}$ & $\begin{array}{c}2014 \\
\text { (No enabled) }\end{array}$ & 2015 & 2016 & Influence \\
\hline Assessment data & $\begin{array}{l}\text { Text material, } \\
\text { manual access }\end{array}$ & $\begin{array}{l}\text { Standardized } \\
\text { information data, } \\
\text { convenient query }\end{array}$ & $\begin{array}{l}\text { Standardized standard } \\
\text { information data to } \\
\text { provide } \\
\text { comprehensive data } \\
\text { query, comparison and } \\
\text { analysis }\end{array}$ & $\begin{array}{l}\text { Platform to enable the } \\
\text { completion of the } \\
\text { assessment process of } \\
\text { information management, } \\
\text { multi-dimensional display } \\
\text { analysis data }\end{array}$ \\
\hline
\end{tabular}

\section{Conclusion}

The application of Higher Vocational Education in the specialty of information management and evaluation platform "reflects the great advantage of Internet plus assessment". Through the application of information technology, it has realized the collection of data from the source to ensure the authenticity of the data real-time accuracy; the fine evaluation index management, more targeted, effective promotion of professional construction; The platform has realized the low cost, the evaluation process of high transparency, fairness and justice. The application of Internet technology can improve the evaluation efficiency, more scientific and comprehensive evaluation. The platform realizes the evaluation of data standardization, information management, data report, which can provide the basis for scientific and accurate evaluation for the construction of two faculties of professional self. It can effectively promote the continuous improvement of professional construction, data display and analysis of multi dimensions, providing decision support for the education department in charge of comprehensive integration of professional construction and management. The platform realizes the interaction with the first professional teachers, strengthen the guidance of workers occupation education and promote the professional setting and industry demand docking, including docking of occupation standard curriculum content; teaching process and the production process; graduation certificate and occupation qualification certificate; occupation education and lifelong learning. With the continuous improvement of data platform in the actual application process function of accumulation, data collection, evaluation, analysis of the integration platform, it will provide the data for the higher vocational education and industry in the region fit analysis, promote the related work of the specialty construction of Higher Vocational Education in the region and contribute to the professional development of Higher Vocational Education in the region.

\section{ACKNOWLEDGEMENT}

The study was supported by the projects of Scientific and Technological Research Program of Chongqing Municipal Education Commission (Grant No. KJ1503204,KJ1731426) and was supported by scientific research and innovation team of Chongqing City Management College.

\section{References}

[1] Information on [http://www.doc88.com/p-2788101649569.html]

[2] Changyin Ren. Review of program evaluation in Chinese colleges, Journal of Hubei University of Economics (SOCIAL SCIENCE EDITION) (2014)

[3] Liu Kangning, Dong Yunchuan. The professional evaluation of higher education should be returned to the main value of the students, Shanghai education evaluation research (2014)

[4] Information on http://www.docin.com/p-347628031.html 